\title{
PERAN ADMINISTRASI KESISWAAN TERHADAP KEMAJUAN PENDIDIKAN DI SEKOLAH
}

\author{
Muhammad Risalan Uzhma \\ Email: 2010128110004@mhs.ulm.ac.id \\ Program Studi Pendidikan IPS Fakultas Keguruan dan Ilmu Pendidikan \\ Universitas Lambung Mangkurat
}

Banjarmasin

\begin{abstract}
Abstrak
Dalam sebuah sekolah terdapat adanya pendidik atau guru, peserta didik atau siswa, tenaga kependidikan dan fasilitas yang terdapat dalam suatu sekolah. Salah satu hal yang penting dalam sebuah sekolah adanya peserta didik atau siswa, karena siswa yang nantinya akan dikembangkan dalam suatu sekolah. Pihak sekolah memiliki peran yang besar terhadap siswa yang belajar disana. Dalam menghadapi siswa, perlu adanya pengelolaan yang baik sehingga siswa tersebut mendapatkan hak dan kewajibannya disekolah tersebut. Administrasi kesiswaan dlihat dari hal pembinaan dan penertiban yang berkaitan satu sama lain dalam sebuah perencanaan atau perancangan untuk siswa. Administrasi kesiswaan dlihat dari hal pembinaan dan penertiban yang berkaitan satu sama lain dalam sebuah perencanaan atau perancangan untuk siswa. Pengelolaan kesiswaan yang baik memiliki ciri-ciri yaitu tepat sasaran, cepat, tanggap, dan memuaskan.
\end{abstract}

Kata Kunci: administrasi,kesiswaan, pendidikan 


\section{PENDAHULUAN}

Sekolah merupakan tempat untuk mencari pengetahuan, namun tidak hanya pengetahuan yang bisa didapatkan, ada juga keterampilan dan perilaku yang baik juga bisa didapatkan dalam sekolah. Dalam sebuah sekolah terdapat adanya pendidik atau guru, peserta didik atau siswa, tenaga kependidikan dan fasilitas yang terdapat dalam suatu sekolah. Salah satu hal yang penting dalam sebuah sekolah adanya peserta didik atau siswa, karena siswa yang nantinya akan dikembangkan dalam suatu sekolah. Siswa atau peserta didik dalam sebuah sekolah diharapkan memiliki kemampuan tidak hanya pengetahuan, namun juga sikap dan keterampilan untuk memberikan kontribusi kesejahteraan untuk masyarakat, dan berbangsa.

Pihak sekolah memiliki peran yang besar terhadap siswa yang belajar disana. Dalam menghadapi siswa, perlu adanya pengelolaan yang baik sehingga siswa tersebut mendapatkan hak dan kewajibannya disekolah tersebut. Pengelolaan terhadap siswa atau yang lebih dikenal dengan administrasi kesiswaan yang memiliki peran terhadap keperluan dari siswa. Administrasi kesiswaan merupakan kumpulan aktivitas perencanaan dan pelaksanaan dalam melayani, membantu, mengarahkan siswa pada sebuah sekolah untuk mencapai tujuan pendidikan. Dalam mencapai tujuan pendidikan, administrasi kesiswaan, tidak dapat melaksanakan dengan sendiri, dan dibantu dengan administrasi lainnya seperti administrasi personel, kurikulum, sarana dan prasarana, organisasi, dan hubungan sekolah dengan masyarakat yang menjadi satu kesatuan dalam sebuah sekolah untuk mencapai tujuan pendidikan bagi siswa.

\section{METODE}

Metode yang digunakan dalam penulisan karya ilmiah ini menggunakan studi pustaka dengan mempelajari dan memahami dari sumber-sumber ilmiah baik dari jurnal ilmiah, dan publikasi ilmiah lainnya untuk mendukung penulisan karya ilmiah dari Peran Administrasi Kesiswaan Terhadap Kemajuan Pendidikan di Sekolah. 


\section{ADMINISTRASI KESISWAAN}

Administrasi kesiswaan adalah kegiatan yang berkaitan dengan siswa untuk mewujudkan dan mengembankan potensi siswa mulai dari masuk sekolah sampai keluar dari sekolah tersebut. Administrasi kesiswaan dlihat dari hal pembinaan dan penertiban yang berkaitan satu sama lain dalam sebuah perencanaan atau perancangan untuk siswa. Menurut Ary Gunawan dalam Akidatul dan Pusvyta, 2019, administrasi sekolah memiliki kegiatan-kegiatan yang dilaksanakan di luar maupun di dalam kelas. Adapun kegiatan yang dilaksanakan di luar kelas meliputi penerimaan siswa baru atau pindahan dari sekolah lain, inventarisasi peserta didik baru yang sekolah tersebut, pendistribusian perlengkapan dan kelengkapan siswa, pembagian kartu anggota OSIS dengan peraturan yang harus dipahami dan dilaksanakan, dan pembinaan peserta didik (bimbingan dan konseling) serta kesejehteraan baik fisik maupun spiritual.

Kegiatan administrasi sekolah yang dilaksanakan di dalam kelas meliputi pengelolaan kelas untuk menciptakan kelas yang kondusif yang digunakan untuk pembelajaran, interaksi yang baik antara guru dan siswa, perhatian terhadap pembelajaran, pemberian remedial jika diperlukan, prestasi yang perlu diperhatikan, tata tertib kelas untuk menunjang pembelajaran, kesesuaian jadwal pembelajaran, pembentukan pengurus kelas, dan pengadaan fasilitas kelas untuk menunjang proses pendidikan. Administrasi kesiswaan yang pada dasarnya berkaitan dengan siswa dan memberikan pelayanan yang baik kepada siswa, dengan harapan inventarisasi dan aktivitas siswa menjadi lebih terarah dan sesuai dengan keinginan sehingga dari pihak sekolah juga dimudahkan dalam mengelola sekolah terutama dalam bidang kesiswaan.

Dalam administrasi kesiswaan tidak akan terlepas dari adanya siswa atau peserta didik karena dalam administrasi kesiswaan yang menjadi hal yang utamanya adalah siswa yang melakukan akivitas di sekolah tersebut. Peserta didik dalam menjalani aktivitasnya disekolah selalu berkaitan dengan administrasi kesiswaan baik dalam hal tata tertib dan sebagainya yang berkaitan dengan peserta didik tersebut. Maka dari itu, disaat seorang peserta didik melakukan sebuah aktivitas baik yang baik ataupun yang baik tentunya akan ada perhatian dari yang dilakukannya. 


\section{ADMINISTRASI KESISWAAN UNTUK KEMAJUAN PENDIDIKAN DI SEKOLAH}

Pengelolaan kesiswaan yang dilakukan oleh pihak sekolah dan semua pihak yang mengaplikasikan berdasarkan yang disampaikan oleh pihak sekolah dalam rangkan untuk mencapai tujuan pendidikan dan kemajuan dari sekolah tersebut yang dampaknya dirasakan oleh semua elemen yang terdapat di sekolah tersebut. Administrasi kesiswaan memiliki tujuan untuk mengatur berbagai kegiatan yang dilakukan dalam bidang kesiswaan dengan tujuan lancar, tertib, dan teratur dalam pembelajaran disekolah untuk mencapai tujuan pendidikan (Mustanir, 2020). Tujuan pendidikan tersebut memiliki peran yang penting yang perlu diperhatikan untuk setiap sekolah, yang nantinya akan berdampak terhadap sekolah tersebut terutama dalam bidang kesiswaan.

Pengelolaan kesiswaan yang baik memiliki ciri-ciri yaitu tepat sasaran, cepat, tanggap, dan memuaskan (Pratiwi, 2020). Hal tersebut sudah seharusnya dimiliki oleh setiap sekolah terutama dalam pengelolaan kesiswaan, sehingga nantinya siswa merasakan perasaan yang puas dan siswa menjadi semangat dalam proses pembelajaran yang baik dan berkualitas untuk tercapainya tujuan pendidikan. Pengelolaan kesiswaan yang benar-benar dilaksanakan dengan baik dan benar, sudah dapat dengan nyata terlihat dari sekolahnya, yang mana sekolah tersebut terlihat kemajuan terutama dari siswanya sehingga sekolah tersebut menjadi sekolah yang memiliki kemajuan dan perkembangan yang lebih pesat.

\section{SIMPULAN}

Sekolah merupakan tempat untuk mencari pengetahuan, namun tidak hanya pengetahuan yang bisa didapatkan, ada juga keterampilan dan perilaku yang baik juga bisa didapatkan dalam sekolah. Salah satu hal yang penting dalam sebuah sekolah adanya peserta didik atau siswa, karena siswa yang nantinya akan dikembangkan dalam suatu sekolah. Siswa juga sebagai penerus bangsa yang nantinya akan menempati bagian-bagian dalam suatu negara. Administrasi kesiswaan adalah kegiatan yang berkaitan dengan siswa untuk mewujudkan dan mengembankan potensi siswa mulai dari masuk sekolah sampai keluar dari sekolah tersebut. Pengelolaan kesiswaan yang 
dilakukan oleh pihak sekolah dan semua pihak yang mengaplikasikan berdasarkan yang disampaikan oleh pihak sekolah dalam rangkan untuk mencapai tujuan pendidikan dan kemajuan dari sekolah tersebut yang dampaknya dirasakan oleh semua elemen yang terdapat di sekolah tersebut.

\section{REFERENSI}

Amalia, N. A. (2020). Hubungan sistem informasi manajemen peserta didik dengan kepuasan orang tua dalam pelayanan administrasi kesiswaan: Penelitian di SMPIT Anni'mah Kabupaten Bandung (Doctoral dissertation, UIN Sunan Gunung Djati Bandung)

BASUKI, C. (2018). PERANCANGAN SISTEM INFORMASI ADMINISTRASI KESISWAAN SD NEGERI 23 MENDOBARAT BERBASIS WEB BERDASARKAN MODEL FAST (Doctoral dissertation, STMIK ATMA LUHUR)

DEWI, G. I. (2018). Keefektifan Pelaksanaan Administrasi Ketatausahaan Sekolah pada SMK YPLP PGRI 1 Makassar (Doctoral dissertation, UNIVERSITAS NEGERI MAKASSAR)

Hermawan, A. (2019). Evaluasi terhadap Pelaksanaan Administrasi Kesiswaan pada Sekolah Menengah Pertama Negeri 1 Kusan Hilir Kabupaten Tanah Bumbu. $A L$ ULUM: Jurnal Ilmu Sosial dan Humaniora, 5(2)

Izza, A., \& Sari, P. (2019). Sistem Informasi Manajemen Untuk Pengelolaan Data Administrasi Kesiswaan Di MA Ihya'ul Ulum Dukun Gresik. Mudir: Jurnal Manajemen Pendidikan, 1(2), 75-88

MUSTANIR, M., Rusmini, R., \& Bawaihi, B. (2021). MANAJEMEN PELAYANAN ADMINISTRASI KESISWAAN DI SEKOLAH MENENGAH ATAS NEGERI 10 KOTA JAMBI (Doctoral dissertation, UIN Sulthan Thaha Saifuddin Jambi)

Mutiani, M., Sapriya, S., Handy, M. R. N., Abbas, E. W., \& Jumriani, J. (2021). Pembinaan Etika Peserta Didik Melalui Pembelajaran Tematik-Integratif Di Sekolah Dasar. Edukatif: Jurnal Ilmu Pendidikan, 3(3), 704-709 
Mutiani, M., WARMANSYAH ABBAS, E. R. S. I. S., Syaharuddin, S., \& Susanto, H. (2019). Penerapan Transcript Based Lesson Analyses (TBLA) Sebagai Upaya Peningkatan Pembelajaran Sejarah Di Sma Negeri 7 Banjarmasin

Pradina, P. I. (2020). PENGARUH KUALITAS PELAYANAN ADMINISTRASI KESISWAAN DAN SARANA PRASARANA PEMBELAJARAN TERHADAP KEPUASAN SISWA KELAS XII DI SMK NEGERI 1 BANDUNG (Doctoral dissertation, Universitas Pendidikan Indonesia)

Sari, R. W. (2020). PENGARUH KUALITAS PELAYANAN ADMINISTRASI KESISWAAN TERHADAP KEPUASAN SISWA DI SEKOLAH MENENGAH KEJURUAN MUHAMMADIYAH 3 PEKANBARU (Doctoral dissertation, UNIVERSITAS ISLAM NEGERI SULTAN SYARIF KASIM RIAU) 